\title{
MINERAL MADDE KAYNAĞI OLARAK BAZI BİTKİ VE BİTKİ ÇAYLARININ ARAŞTIRMASI
}

\author{
Emine NAKİLCİOĞLU-TAŞ ${ }^{\mathbf{1}}$ (ORCID: 0000-0003-4334-2900) ${ }^{*}$
}

${ }^{1}$ Ege Üniversitesi, Mühendislik Fakültesi, Gıda Mühendisliği Bölümü, Bornova, İZMíR

Gelis / Received: 12.02 .2019 Kabul / Accepted: 31.05 .2019

\begin{abstract}
ÖZ
Pek çok bitki çayının sağlık üzerine olumlu etkilere sahip olduğu bilinmektedir. Fakat mineral madde içerikleri hakkında sınırlı sayıda çalışma bulunmaktadır. Bu çalışmada Türkiye'de tıbbi amaçlarla kullanılan kekik (Thymus vulgaris L.), nane (Mentha piperita), sinameki (Cassia angustifolia), biberiye (Rosmarinus officinalis), rezene (Foeniculum vulgare), papatya (Matricaria chamomilla), 1hlamur (Tilia vulgaris), adaçayı (Salvia officinalis), yeşilçay (Camellia sinensis) ve ısırgan otu (Urtica dioical) bitkisinin ve bunlardan infüzyon yöntemiyle elde edilen çayların mineral madde içerikleri ( $\mathrm{Zn}, \mathrm{Mn}, \mathrm{Na}, \mathrm{K}, \mathrm{Cu}, \mathrm{Ca}, \mathrm{Fe}, \mathrm{Mg}$ ve $\mathrm{P}$ ) araştırılmıştır. Mineral maddelerin infüzyon yöntemiyle bitki çayına ekstrakte edilme oranları tespit edilmiştir. Bitki ve bitki çaylarının mineral madde içerikleri geniş bir aralıkta değişkenlik göstermiştir. Mineral maddelerin ekstrakte edilebilirliği \% 41,57 - \% 60,37 arasında değişmiştir. Ekstrakte edilebilirliği en yüksek olan mineral K (\% 32,73 - \% 70,69), en düşük olan ise Fe (\% 12,05 - \% 0,39) olarak belirlenmiştir. Düzenli bitki çayı tüketimiyle, günlük mineral ihtiyacını karşılamaya katkı sağlanabilir.
\end{abstract}

Anahtar kelimeler: Bitki, bitki çayı, infüzyon yöntemi, mineral madde

\section{INVESTIGATION OF SOME HERBS AND THEIR INFUSIONS AS MINERAL RESOURCES}

\begin{abstract}
Many herbal teas are known to have positive health effects. However, there are limited studies on their mineral contents. In this study, the mineral contents ( $\mathrm{Zn}, \mathrm{Mn}, \mathrm{Na}, \mathrm{K}, \mathrm{Cl}, \mathrm{Ca}, \mathrm{Fe}, \mathrm{Mg}$ and $\mathrm{P}$ ) of thyme (Thymus vulgaris L.), mint (Mentha piperita), senna (Cassia angustifolia), rosemary (Rosmarinus officinalis), fennel (Foeniculum vulgare), chamomile (Matricaria chamomilla), linden (Tilia vulgaris), sage (Salvia officinalis), greens (Camellia sinensis) and nettle (Urtica dioical) herbs used for medicinal purposes in Turkey and their infusions were investigated. The extraction rate of minerals into herbal tea by infusion method was determined. The mineral contents of herbs and their infusions showed a wide variability. The extractability of minerals varied between $41.57 \%$ and $60.37 \%$. The mineral with the highest extractability was $\mathrm{K}(32.73 \%-70.69 \%)$ and the lowest one was Fe $(12.05 \%-0.39 \%)$. Regular herbal tea consumption can contribute to meeting the daily mineral requirements.
\end{abstract}

Keywords: Herb, herbal tea, infusion method, mineral

${ }^{*}$ Corresponding author / Sorumlu yazar. Tel.: +90 232 3113007; e-mail / e-posta: emine.nakilcioglu@ @ege.edu.tr 


\section{GíRiş}

Camellia sinensis L. yapraklarının veya tomurcuklarının demlenmesiyle elde edilen çay, dünyada sudan sonra en çok tüketilen içecektir [1]. Günümüzde Camellia sinensis bitkisinin yapraklarından ya da farklı bitki türlerinden elde edilen çaylar, günlük diyetin vazgeçilmezlerindendir [2]. Bitki çayları, bitkilerin yapraklarından, çiçeklerinden, tohumlarından, meyvelerinden, saplarından veya köklerinden su varlığında hazırlanmaktadır [3]. Bitki çaylarını hazırlamada infüzyon, dekoksiyon ve soğuk maserasyon olmak üzere üç yöntemden faydalanılabilmektedir. İnfüzyon yönteminde, bitki üzerine kaynar su dökülür ve 5 - 10 dakika bekletilir. Daha sonra çay süzülür. Hassas dokular için (örneğin yapraklar, çiçekler) infüzyon yönteminin kullanımı önerilmektedir. Dekoksiyon (kaynatma) yönteminde, bitki soğuk suyla karıştırılarak 5 - 10 dakika süreyle kaynatılır ve çay süzülür [4]. Dekoksiyon yönteminin çok geçirgen kompakt dokularda (odunsu kısımlar, kökler, tohumlar vb.) kullanımı uygundur [5]. Soğuk maserasyonda ise bitkinin üzerine soğuk su ilave edilir ve oda sıcaklığında 6 - 8 saat bekletilir. Ardından, çay süzülür. Soğuk maserasyon metodu, marshmallow kökü, keten tohumu ve psyllium gibi yüksek müsilaj içerikli bitkiler için kullanılmaktadır [4]. Kullanılan hazırlama yöntemine bağlı olarak 10 - 20 g bitkiden genellikle bir litre çay elde edilmektedir. Çay hazırlandıktan sonra isteğe göre tatlandırılabilir ve hemen tüketilmelidir [5].

Bitki çaylarının popülerliği, temel olarak tıbbi bitki ve bitki çayı çeşidinin sayıca fazla olması, düşük fiyatları, yan etkilerinin ve çevreye verdikleri zararın oldukça düşük olması ve son zamanlarda ilaçların yerini alma veya ilaçların etkilerine destek olma eğilimleri ile ilgilidir [6]. Bitki çayları demir, magnezyum, manganez, potasyum ve çinko gibi minerallerin, çeşitli vitaminlerin ve antioksidan bileşiklerin iyi kaynaklarındandır $[7,8]$. Bu sebeple solunum sistemi, gastrointestinal sistem ve idrar yoluyla ilgili bazı enflamatuar kaynaklı hastalıkların önlenmesi ve tedavisi amacıyla alternatif tıpta sıklıkla kullanılmaktadırlar [9].

Bazı mineraller belirli biyolojik aktivitelere sahipken, bazılarının toksik olabilmesi sebebiyle, bitki çaylarının ve tıbbi bitkilerin mineral içeriklerinin belirlenmesi, besleyici ve sağlık etkilerinin yanı sıra insan diyetindeki rollerini anlamak için de gereklidir. Genellikle, bitki çayları ve tıbbi bitkiler yüksek miktarda esansiyel mineralleri (çinko $(\mathrm{Zn})$, mangan $(\mathrm{Mn})$, sodyum $(\mathrm{Na})$, potasyum $(\mathrm{K})$, kalsiyum $(\mathrm{Ca})$, demir $(\mathrm{Fe})$, magnezyum $(\mathrm{Mg})$ ve fosfor $(\mathrm{P})$ ) içermektedir. Ancak, bu minerallerin konsantrasyonları bitkisel materyale bağlı olarak oldukça geniş aralıklarda değişmektedir. Tıbbi bitkilerden bitki çayı elde edilirken, yapıda bulunan organik matriks bileşenleriyle birlikte mineraller, sıvı ortama ayrı ayrı ekstrakte olmakta ve böylece bitki çayı, insan diyetinde bazı sağlık etkileri yaratabilecek majör, minör ve eser minerallerin kaynağı haline gelmektedir. Minerallerin çoğu ilk 2-3 dakika içinde ekstrakte olabilmektedir [6].

Ülkemizde yaygın olarak tüketilen birçok bitki çayı çeşidi bulunmaktadır. Bu ürünler arasında yeşil çay, ıhlamur ve adaçayı tıbbi veya sağlığın korunması amacıyla kullanılan en popüler ürünlerdir [10]. Bazı bitki ve o bitkilerden elde edilen çaylarının mineral içeriği, literatürde yer alan bazı çalışmalarca belirlenmiştir [11-17].

Tıbbi bitkilerin özellikle esansiyel mineral madde içeriklerinin yüksek olması, insan sağlığını destekleyici etkileri sebebiyle her ne kadar önemli olsa da, bu bitkilerin içerdiği mineral maddelerin çay formuna geçme oranları daha önemlidir. Bitkilerin mineral madde içeriklerinin çay formuna ekstrakte edilebilirliği ne kadar yüksekse, vücuda o oranda yüksek mineral madde alınabilir. Bu sebeple bitkilerin mineral madde içeriğginden ziyade, bitki çaylarının mineral madde miktarları ve her bir mineralin çay formuna ekstrakte edilebirliği önem arz etmektedir. Bu çalışmanın amacı ülkemizde sıklıkla kullanılan 10 farklı bitkinin ve bu bitkilerden infüzyon yöntemi ile elde edilen bitki çaylarının, mineral madde ( $\mathrm{Zn}, \mathrm{Mn}, \mathrm{Na}, \mathrm{K}, \mathrm{Cu}, \mathrm{Ca}, \mathrm{Fe}, \mathrm{Mg}$ ve $\mathrm{P}$ ) içeriklerinin belirlenmesi; mineral maddelerin bitki çayına ekstrakte olma oranlarının ortaya konulması ve günlük alınması önerilen mineral madde miktarına bitki çayı tüketiminin etkisinin belirlenmesidir.

\section{MATERYAL VE METOT}

\subsection{Materyal}

Analizlerde kullanılmak üzere 10 farklı bitki İzmir'de bulunan bir marketten (Migros A. Ş.) ve aktardan temin edilmiştir (Tablo 1). Bunlardan rezene tohumu 2 g'lık, yeşil çay yaprağ 1,75 g'lık, ıhlamur çiçeği 1,5 g'lık, papatya çiçeği 1,3 g'lık, adaçayı yaprağı 1 g'lık poşet çay şeklinde 20 kullanımlık ambalajlardaydı. Kekik yaprağı, nane yaprağı, sinameki yaprağı, biberiye yaprağı ve 1 sırgan otu sap ve yaprağı 100 g'lık poşet ambalajlarda satın alınmış ve analizden önce ögütülmüştür. 


\subsection{Metot}

\subsection{1. Örnek hazırlama}

\subsubsection{Bitki çaylarının hazırlanması}

Analizde kullanılacak bitkiler, infüzyon yöntemi kullanılarak çay eldesine uygun olduğundan bitki çaylarının hazırlanmasında infüzyon yöntemi tercih edilmiştir. Bu amaçla cam kupa bardağa koyulan $2 \mathrm{~g}$ bitki örneği üzerine $200 \mathrm{~mL} 80^{\circ} \mathrm{C}$ sıcaklığında tridestile su ilave edilmiş̧ir. Yeşil çay için $5 \mathrm{dk}$ ve diğer bitkiler için $10 \mathrm{dk}$ demleme süresinin sonunda, Whatman no.1 filtre kağıldı yardımıyla süzme işlemi uygulanmış ve elde edilen bitki çayları, oda sıcaklığında soğumaya bırakılmıştır. Elde edilen bitki çaylarının toplam hacimleri $200 \mathrm{~mL}$ 'ye tekrardan tamamlanmıştır ve analizden önce uygun oranda asitlendirilmiştir..

Tablo 1. Bitkilerin genel ve latince isimleri

\begin{tabular}{|c|c|}
\hline Genel ismi & Latince ismi \\
\hline Kekik & Thymus vulgaris $\mathrm{L}$. \\
\hline Nane & Mentha piperita \\
\hline Sinameki & Cassia angustifolia \\
\hline Biberiye & Rosmarinus officinalis \\
\hline Rezene & Foeniculum vulgare \\
\hline Papatya & Matricaria chamomilla \\
\hline Ihlamur & Tilia vulgaris \\
\hline Adaçay1 & Salvia officinalis \\
\hline Yeşilçay & Camellia sinensis \\
\hline Isırgan otu & Urtica dioical \\
\hline
\end{tabular}

\subsubsection{Mikrodalga-destekli yaş yakma}

Bitki örneklerinden mineral maddeler, Szymczycha-Madeja ve ark. (2014) [18]'nın modifiye edilmiş yöntemleri kullanılarak ekstrakte edilmiştir. Örnekler $(0.5 \mathrm{~g})$ teflon numune kaplarına tartılmış ve üzerlerine, 1 $\mathrm{mL} \% 30(\mathrm{v} / \mathrm{v}) \mathrm{H}_{2} \mathrm{O}_{2}$ çözeltisi ile $6 \mathrm{~mL}$ konsantre $\mathrm{HNO}_{3}$ çözeltisi ilave edilmiştir. Numune kaplarının kapakları kapatılmış ve reaksiyon karışımları vakit kaybetmeden mikrodalga-destekli yaş yakma sisteminde (Erghof Speedwave Microwave Digestion, Almanya) ısıtmaya maruz bırakılmıştır. Bu amaçla karışımlar 90 W'da ilk 10 $\mathrm{dk} 170^{\circ} \mathrm{C}, 15 \mathrm{dk} 200^{\circ} \mathrm{C}$, son olarak da $20 \mathrm{dk}$ süreyle $75^{\circ} \mathrm{C}$ sıcaklığa tabi tutulmuştur. Soğuduktan sonra, çözeltiler süzülmüş ve hacimleri $25 \mathrm{~mL}$ 'ye tridestile su ile tamamlanmıştır.

\subsubsection{Mineral madde analizi}

\subsubsection{Atomik Absorpsiyon Spektrofotometresi (AAS) ile mineral madde analizi}

Bitki ve bitki çaylarının $\mathrm{Zn}, \mathrm{Mn}, \mathrm{Na}, \mathrm{K}, \mathrm{Cu}, \mathrm{Ca}, \mathrm{Fe}$ ve $\mathrm{Mg}$ içerikleri AAS (Analytik Jena ContrAA 700, Almanya) yardımıyla belirlenmiştir. Tablo 2'de verildiği üzere, analiz öncesinde cihazda tespit edilen optimum çalışma koşulları mineral maddelerin tespitinde kullanılmıştır. 
Tablo 2. Bazı bitkilerin ve bitki çaylarının mineral madde içeriklerinin belirlenmesi için kullanılan optimum AAS çalışma koşulları

\begin{tabular}{|l|l|}
\hline Alev tipi & Asetilen $\left(\mathrm{C}_{2} \mathrm{H}_{2}\right):$ Hava \\
\hline Bek yüksekliği & $4 \mathrm{~mm}(\mathrm{Ca}$ analizinde $)$ \\
\hline & $5 \mathrm{~mm}(\mathrm{Cu}$ ve $\mathrm{Mg}$ analizlerinde $)$ \\
\hline & $6 \mathrm{~mm}(\mathrm{Zn}, \mathrm{Mn}$ ve $\mathrm{K}$ analizlerinde $)$ \\
\hline Yakıt besleme debisi & $7 \mathrm{~mm}(\mathrm{Na}$ ve $\mathrm{Fe}$ analizlerinde $)$ \\
\hline & $40 \mathrm{~L} / \mathrm{sa}(\mathrm{Cu}, \mathrm{Ca}, \mathrm{Mg}, \mathrm{Mn}$ ve $\mathrm{Na}$ analizlerinde $)$ \\
\hline Oksidan besleme debisi & $50 \mathrm{~L} / \mathrm{sa}(\mathrm{Fe}, \mathrm{Zn}$ ve $\mathrm{K}$ analizlerinde $)$ \\
\hline Yakıt: Oksidan oranı & $470 \mathrm{~L} / \mathrm{sa}$ \\
\hline & $0,085(\mathrm{Cu}, \mathrm{Mn}, \mathrm{Ca}, \mathrm{Mg}$ ve $\mathrm{Na}$ analizlerinde $)$ \\
\hline Calışılan dalgaboyu & $0,106(\mathrm{Fe}, \mathrm{Zn}$ ve $\mathrm{K}$ analizlerinde $)$ \\
\hline & $\mathrm{Zn}(213,9 \mathrm{~nm})$ \\
\hline & $\mathrm{Mn}(279,5 \mathrm{~nm})$ \\
\hline & $\mathrm{Na}(589 \mathrm{~nm})$ \\
\hline & $\mathrm{K}(766,5 \mathrm{~nm})$ \\
\hline & $\mathrm{Cu}(324,7 \mathrm{~nm})$ \\
\hline & $\mathrm{Ca}(422,7 \mathrm{~nm})$ \\
\hline & $\mathrm{Fe}(248,3 \mathrm{~nm})$ \\
\hline & $\mathrm{Mg}(285,2 \mathrm{~nm})$ \\
\hline
\end{tabular}

Örnek, standart ve kör çözeltilere $\mathrm{Zn}, \mathrm{Mn}, \mathrm{Cu}, \mathrm{Ca}, \mathrm{Fe}$ ve $\mathrm{Mg}$ analizlerinde girişimi engellemek amaciyla \% 1 (w/v) $\mathrm{LaCl}_{2}, \mathrm{~K}$ analizinde $\mathrm{Na}$ çözeltisi, $\mathrm{Na}$ analizinde ise $\mathrm{K}$ çözeltisi ilave edilmiştir. Her örneğe $1 \mathrm{ppm}$ ilgili mineral maddeden ilave edilerek kullanılan AAS yöntemlerinin geri kazım değerleri ve cihaz yardımıyla metotlara ait teşhis limitleri (LOD) ve tespit limitleri (LOQ) belirlenmiştir.

\subsubsection{UV/Vis spektrofotometre ile $P$ analizi}

Bitki ve bitki çaylarının P içerikleri AOAC (1996) [19] yönteminin modifiye edilmesiyle spektrofotometrik olarak Uv/Vis Spektrofotometre (UV-1280 UV-VIS Spektrofotometre, Shimadzu Corporation, Japonya) kullanımıyla tespit edilmiştir. 0, 10, 20, 30, 40,50,60 mg/L konsantrasyona sahip $\mathrm{P}_{2} \mathrm{O}_{5}$ standartlarının ve ilgili oranda seyreltilmiş örneklerin üzerine $20 \mathrm{~mL}$ molibdovanat çözeltisi ilave edilmiş ve toplam hacim $50 \mathrm{~mL}$ 'ye tamamlanmıştır. $10 \mathrm{dk}$ süreyle karanlık ortamda bekletilmelerinin ardından absorbansları $460 \mathrm{~nm}$ 'de okunmuştur. $\mathrm{P}_{2} \mathrm{O}_{5}$ standartlarından çizilen kalibrasyon eğrisi kullanılarak, örneklerin $\mathrm{P}$ miktarları belirlenmiştir.

\subsection{3 İstatistiksel analiz}

Analizler 2 tekrar 3 paralel şeklinde gerçekleştirilmiş ve elde edilen sonuçlar SPSS 20.0 paket programı kullanılarak tek yönlü varyans analizi (ANOVA) ve Duncan testi yardımıyla istatistiksel açıdan değerlendirilmiştir. Bitki ve bitki çayı örneklerinin mineral madde içerikleri arasında anlamlı bir farklılı̆ğn olup olmadığının belirlenmesi için, her bir mineral madde kendi içinde değerlendirilmiştir $(p<0,05)$.

\section{BULGULAR VE TARTIŞMA}

Bitki ve bitki çayı örneklerinin mineral madde içeriklerini belirlemede kullanılan yöntemlerin performans özellikleri, Tablo 3'de verilmiştir. Kalibrasyon grafikleri, mineral maddelerin 4 farklı konsantrasyonu için ü̧̈ tekrarlı okuma sonucunda elde edilen cevaplardan oluşturulmuştur. Çalışma aralığının doğrusallı̆̆ı, her mineral madde için iyi bir regresyon katsayısıyla belirlenmiş̧tir $(0,9462-0,9981)$. Geri kazanım değerleri \% 79 ile \% 
107, LOD değerleri $0,0923 \mathrm{mg} / \mathrm{L}$ ile $2,6020 \mathrm{mg} / \mathrm{L}$ ve LOQ değerleri ise $0,3481 \mathrm{mg} / \mathrm{L}$ ile $8,6735 \mathrm{mg} / \mathrm{L}$ arasında değişmiştir.

Tablo 3. Mineral madde tayininde kullanılan yöntemlerinin performans karakteristikleri

\begin{tabular}{|c|c|c|c|c|c|}
\hline Mineral madde & $\begin{array}{c}\text { Kalibrasyon eğrisinin } \\
\text { aralığı (mg/L) }\end{array}$ & $\begin{array}{c}\text { Korelasyon } \\
\text { katsayssı (r) }\end{array}$ & $\begin{array}{c}\text { Geri kazanım } \\
(\mathbf{\%})\end{array}$ & $\begin{array}{c}\text { LOD } \\
(\mathbf{m g} / \mathbf{L})\end{array}$ & $\begin{array}{c}\mathbf{L O Q} \\
(\mathbf{m g} / \mathbf{L})\end{array}$ \\
\hline $\mathbf{Z n}$ & $0,2-1,5$ & 0,9669 & $85-98$ & 0,1879 & 0,6848 \\
\hline $\mathbf{M n}$ & $0,2-1,5$ & 0,9979 & $90-102$ & 0,0923 & 0,3481 \\
\hline $\mathbf{N a}$ & $1-2,5$ & 0,9462 & $81-94$ & 0,4871 & 1,6380 \\
\hline $\mathbf{K}$ & $0,5-4$ & 0,9957 & $89-107$ & 0,3288 & 1,2310 \\
\hline $\mathbf{C u}$ & $0,5-4$ & 0,9782 & $85-99$ & 0,3136 & 1,1700 \\
\hline $\mathbf{C a}$ & $1-4$ & 0,9879 & $83-95$ & 1,1390 & 4,3760 \\
\hline $\mathbf{F e}$ & $0,5-3,75$ & 0,9972 & $89-104$ & 0,2028 & 0,7700 \\
\hline $\mathbf{M g}$ & $0,2-1,5$ & 0,9466 & $81-97$ & 0,4678 & 1,9600 \\
\hline $\mathbf{P}$ & $10-60$ & 0,9981 & $79-85$ & 2,6020 & 8,6735 \\
\hline
\end{tabular}

10 farklı bitki ve bitki çayında, 9 farklı mineral maddenin belirlenen miktarları Tablo 4 ve Tablo 5 'te verilmektedir. Ayrıca bitkide yer alan mineral maddelerin bitki çayına geçme yüzdeleri de Tablo 6'da gösterilmektedir. Bitkilerin ve bitki çaylarının önemli miktarda mineral madde içerdikleri gözlemlenmiştir. İncelenen tüm mineral maddeler kümülatif değerlendirildiğinde, mineral madde içeriği en yüksek olan bitkiler sinameki $(4,52 \mathrm{mg} / \mathrm{g})$, ihlamur $(4,55 \mathrm{mg} / \mathrm{g})$ ve 1 sırgan otu $(4,60 \mathrm{mg} / \mathrm{g})$ iken, $2 \mathrm{~g}$ bitkinin infüzyonuyla hazırlanan bitki çayları arasında mineral madde içeriği en yüksek olan çay çeşidi, sinameki çayı $(5,19 \mathrm{mg} / 200 \mathrm{~mL})$ 'dır $(p<0,05)$. Ayrıca, sinameki $(\% 57,37)$ ve yeşilçay $(\% 60,37)$, infüzyon yöntemiyle mineral madde ekstrakte edilebilirliğinin en yüksek saptandığı bitkilerdir $(p<0,05)$. Bitki ve bitki çayları incelendiğinde, içerdikleri mineral maddelerin miktarının geniş bir aralıkta değişim gösterdiği söylenebilir.

Zn, karbonhidrat ve protein sentezinde görev alan bazı enzimlerin yapısında ve aktivasyonunda rol alan bir mineraldir. Zn eksikliğinde ise iştah azalması, gelişme geriliği ve deride parakeratozis lezyonları ortaya çıkmaktadır [20]. Zn içeriği en yüksek olan bitkiler 1sırgan, adaçayı ve biberiye $(91,07-93,69 \mu \mathrm{g} / \mathrm{g})$ iken, en düşük olan bitki ise papatya $(64,69 \mu \mathrm{g} / \mathrm{g})$ olarak saptanmıştır $(p<0,05)$. Çay örnekleri arasında bir su bardağı $(200 \mathrm{~mL})$ rezene çayında $\mathrm{Zn}$ miktarının maksimum seviyede $(76,15 \mu \mathrm{g})$, biberiye çayında ise minimum seviyede $(29,23 \mu \mathrm{g})$ bulunduğu gözlemlenmiştir $(p<0,05)$. İnfüzyon yöntemiyle $\mathrm{Zn}$ mineralinin bitki çayına ekstrakte edilme oranı \% 15,91 (biberiye) ile \% 53,13 (rezene) arasında belirlenmiştir. Bu çalışmada bitkilerin içerdiği Zn miktarları, Başgel ve Erdemoğlu (2006) [11] ve Gallaher ve ark. (2006) [12]'nın çalışmalarında buldukları miktarlardan yüksektir. Nane çayının ve yeşil çayın Zn içeriklerinin, Gallaher ve ark. (2006) [12] tarafından daha düşük bulgulandığı görülmektedir. Zn'nun infüzyon yöntemiyle çay fazına ekstrakte edilebilirliğinin de rezene, ıhlamur ve ısırgan otu örnekleri dışında araştırılan diğer bitkilerde, Başgel ve Erdemoğlu (2006) [11] ve Gallaher ve ark. (2006) [12]'nın tespit ettiği değerlerden daha düşük saptandığı gözlemlenmektedir.

Mn, pek çok esansiyel enzimi aktive eden bir mineraldir [18]. Eksikliğinde işitme kaybı, ataksi, diyabet, tendon ve bağlarda zayıflıkla karşı karşıya kalınabilmektedir [21]. 10 farklı bitkinin Mg miktarları, 3,99 (rezene) - 249,32 $\mu \mathrm{g} / \mathrm{g}$ (yeşilçay) arasında değişiklik göstermiştir $(p<0,05)$. Bu bitkilerden elde edilen çaylar arasında yeşilçayın Mn içeriği en yüksek $(292,72 \mu \mathrm{g} / 200 \mathrm{~mL})$ iken, biberiye çayı, rezene çayı ve 1 sırgan otu çayında $\mathrm{Mn}$ varlığ 1 tespit edilememiştir $(p<0,05)$. Sinameki çayında Mn mineralinin ekstrakte edilebilirliği \% 62,64 olarak saptanması sonucunda, infüzyon yöntemiyle Mn ekstrakte edilebilirliği en yüksek olan bitki sinameki olarak belirlenmiş̧iir $(p<0,05)$. Biberiye, rezene ve isırgan otunun $\mathrm{Mn}$ içerikleri ise, infüzyon yöntemiyle ekstrakte edilememiştir. Bitkilerin Mn içeriklerinin Başgel ve Erdemoğlu (2006) [11]'nun belirttiği sonuçlardan düşük, Pytlakowska ve ark (2012) [15]'nınkilerden ise yüksek olduğu ortaya çıkmıştır. Isırgan otu çayı hariç diğer çayların Mn içerikleri Pytlakowska ve ark (2012) [15]'nın çalışmalarında ortaya koyduklarından daha yüksek tespit edilmiş̧tir. Oysaki çayların içerdiği Mn miktarları, Başgel ve Erdemoğlu (2006) [11]'nun rapor ettiğgi sonuçlardan daha düşüktür. İnfüzyonla Mn mineralinin ekstrakte edilebilirlik oranı, sinameki hariç diğer bitki çaylarında Başgel ve Erdemoğlu (2006) [11]'nun çalışmasından daha düşük bulunmuştur.

$\mathrm{Na}$, vücuttaki pekçok düzenleyici sistem için büyük öneme sahiptir. Ter ile vücuttan atılır. İshal ve kusma vücutta Na kaybına yol açmaktadır [14]. Yeşilçayda $\mathrm{Na}, 0,11 \mathrm{mg} / \mathrm{g}$ 'la minimum, papatyada ise $0,44 \mathrm{mg} / \mathrm{g}$ 'la 


\section{E. NAKILCIOĞLU-TAŞ}

maksimum miktarda elde edilmiştir ( $p<0,05$ ). Bitki çaylarında Na, 0,08 (yeşil çay) ile 0,46 mg/200 mL (papatya) arasında değişmiştir $(p<0,05)$. Yeşil çay ve adaçayının infüzyonlarında tespit edilen $\mathrm{Na}$ miktarları arasında istatistiksel açıdan anlamlı bir fark tespit edilememiştir $(p>0,05)$. İnfüzyon yöntemiyle Na mineralinin ekstrakte edilebilirliğinin en düşük olduğu bitki, adaçayı (\% 27,99)'dır ( $p<0,05)$. Isırgan otu $(\% 53,36)$, nane $(\% 53,52)$ ve rezene $(\%$ 55,40)'de $\mathrm{Na}$ ekstrakte edilebilirliği en yüksektir ve aralarında anlamlı bir farklılık belirlenememiştir $(p>0,05)$. Bitkilerden adaçayı ve bitki çaylarından da 1sırgan otu çayı dışındaki tüm örneklerin Na içeriği Pytlakowska ve ark (2012) [15]'nın bulgularından daha düşüktür. Na mineralinin infüzyonla ekstrakte edilebilirliği ise nane çayında ve yeşilçayda Gallaher ve ark (2006) [12]'nın bulgularından daha düşük değerdedir.

$\mathrm{K}$, Na ile birlikte, ozmotik basıncın sürdürülmesi, asit-baz dengesinin sağlanması, kas işlevleri ve sinir uyarılarının iletilmesi gibi önemli metabolik ve fizyolojik olaylarda görev alan bir mineral maddedir [20]. K içeriği en düşük iki bitki sırasıyla nane $(0,55 \mathrm{mg} / \mathrm{g})$ ve 1 sırgan otu $(0,61 \mathrm{mg} / \mathrm{g})$ olarak tespit edilmiştir $(p<0,05)$. Diğer bitkilerin $\mathrm{K}$ miktarları birbirine benzerdir $(1,12-1,14 \mathrm{mg} / \mathrm{g})$ ve aralarında anlamlı bir farklılık saptanmamıştır $(p>0,05)$. Adaçayı $(1,61 \mathrm{mg} / 200 \mathrm{~mL})$, yeşilçay $(1,59 \mathrm{mg} / 200 \mathrm{~mL})$ ve 1 hlamur çayı $(1,59 \mathrm{mg} / 200$ $\mathrm{mL})$ en yüksek K içeriğine sahip çay türleri iken $(p>0,05), 0,72 \mathrm{mg} / 200 \mathrm{~mL} \mathrm{~K}$ içeriğiyle nane çayı en düşük K içerikli bitki çayı olarak gözlenmiştir $(p<0,05)$. Papatya, infüzyon ile $\mathrm{K}$ ekstrakte edilebilirliğinin en düşük $(\%$ $32,73)$ olduğu bitkidir. Kekik, sinameki, ıhlamur, adaçayı ve yeşilçay ise infüzyon işlemiyle $\mathrm{K}$ ekstrakte edilebilirliğinin en yüksek (\% 68,55 - \% 70,69) olduğu bitkilerdir ve aralarında istatistiksel açıdan önemli bir farklılık bulunamamıştır $(p>0,05)$. Bitki ve bitki çaylarında tespit edilen K miktarları Özcan ve ark (2008) [14]'nın bulgularından daha düşüktür. K mineralinin infüzyon yöntemiyle ekstrakte edilebilme oranı ise Gallaher ve ark (2006) [12]'nın nanede ve yeşil çayda belirledikleri değerlerden daha düşüktür.

$\mathrm{Cu}$, sitokrom c oksidaz, superoksit dismutaz, tirozinaz, dopamin $\alpha$-hidroksilaz ve lizil oksidaz gibi enzimlerin kofaktörüdür ve hücrede solunum, bağ doku gelişimi, kemik oluşumu ve hemoglobin sentezinde rol oynamaktadır [20,21]. Bitki ve bitki çaylarının diğer minerallere kıyasla $\mathrm{Cu}$ içeriklerinin oldukça düşük olduğu gözlemlenmiştir. 6,44 $\mu \mathrm{g} / \mathrm{g}$ miktarıyla $\mathrm{Cu}$ içeriği en yüksek olan bitki, nanedir $(p<0,05)$. Cu miktarı en düşük olan bitkiler ise sinameki $(2,26 \mu \mathrm{g} / \mathrm{g})$ ve biberiye $(2,35 \mu \mathrm{g} / \mathrm{g})$ ' dir ve aralarında anlamlı bir farklılık gözlenmemiştir $(p>0,05)$. Bitki çaylarının $\mathrm{Cu}$ içerikleri ve infüzyon yöntemiyle $\mathrm{Cu}$ mineralinin ekstrakte edilebilirliği sırasıyla 0,93 (biberiye çayı) - 8,65 $\mu \mathrm{g} / 200 \mathrm{~mL}$ (kekik çayı) ve \% 19,62 (biberiye) - \% 71,13 (kekik) aralığında değişim göstermiştir $(p<0,05)$. Bitki ve bitki çaylarında saptanan Cu miktarları ile infüzyon tekniği yardımıyla $\mathrm{Cu}$ mineralinin ekstrakte edilme oranı, Başgel ve Erdemoğlu (2006) [11]'nun sonuçlarından daha düşüktür. Sadece rezeneden $\mathrm{Cu}$ mineralinin ekstrakte edilebilirliği, bu çalışmayla benzer değerdedir.

$\mathrm{Ca}$, kemik ve dişlerin ana bileşenidir. Hücre zarlarında ve kaslarda, endo- ve ekzoenzimlerin düzenlenmesi ve kan basıncı regülasyonunun sağlanması gibi önemli işlevlere sahiptir [14]. En yüksek Ca içeren bitki, 1sırgan otu $(1,18 \mathrm{mg} / \mathrm{g})$ olarak tespit edilmiştir $(p<0,05)$. Yeşilçay $(0,05 \mathrm{mg} / \mathrm{g})$ ve rezenenin $(0,06 \mathrm{mg} / \mathrm{g}) \mathrm{Ca}$ içerikleri arasında istatistiksel olarak önemli bir farklılık gözlenmemiş $(p>0,05)$ ve tüm bitkiler arasında en düşük Ca içeriğine sahip oldukları belirlenmiştir $(p<0,05)$. Sinameki çayı, $0,95 \mathrm{mg} / 200 \mathrm{~mL}$ Ca içeriğiyle en yüksek Ca içeren bitki çayı olarak tespit edilmiştir. Yeşilçay, biberiye çayı, rezene çayı ve papatya çayı ise, $200 \mathrm{~mL}$ 'sinde 0,03-0,04 mg Ca bulundurmalarıyla, araştırılan bitki çayları arasında Ca içeriği en düşük olan çaylar olarak bulgulanmıştır $(p>0,05)$. Bitkilerden infüzyon yöntemiyle $\mathrm{Ca}$ mineralinin ekstrakte edilme oranı geniş bir aralıkta (\% 5,76 (biberiye) - \% 77,90 (1hlamur)) değişim göstermiştir. Bitki ve bitki çaylarında belirlenen Ca miktarları, infüzyon yöntemiyle hazırlanan yeşilçay haricindeki diğer örneklerde Özcan ve ark (2008) [14]'nın çalışmasında belirlenen değerlerden daha düşüktür. Nane ve yeşilçaydan infüzyon yöntemiyle Ca mineralinin ekstrakte edilme oranı ise Gallaher ve ark (2006) [12]'nın bulgularından daha yüksek tespit edilmiştir.

Fe, elektron taşınmasında, oksijen taşınması ve depolanmasında, oksidatif metabolizmada, hücre büyümesi ve bölünmesinde, vücut için elzem reaksiyonların katalizinde kullanılan, yaşam için vazgeçilmez bir mineral maddedir [21]. Bitkilerin Fe içerikleri oldukça yüksek iken, bitki çaylarının Fe miktarları çok daha düşüktür. Bitkilerin Fe içerikleri 68,34 (rezene) ile 619,44 $\mu \mathrm{g} / \mathrm{g}$ (nane) arasında değişim göstermiştir. Fe miktarı en yüksek tespit edilen $(33,37 \mu \mathrm{g} / 200 \mathrm{~mL})$ bitki çayı ve infüzyon metodu ile Fe mineralinin ekstrakte edilme oranı $(\%$ $12,05)$ en yüksek olan bitki, yeşilçaydır $(p<0,05)$. Biberiye çayı ve kekik çayı ise sırasıyla $2,24 \mu \mathrm{g} / 200 \mathrm{~mL}$ ve $2,94 \mu \mathrm{g} / 200 \mathrm{~mL}$ Fe içerikleriyle, en düşük Fe içeriğine sahip bitki çayları olarak tespit edilmiştir $(p<0,05)$ ve aralarında anlamlı bir farklılık bulunamamıştır $(p>0,05)$. Benzer şekilde, infüzyon tekniği ile Fe mineralinin ekstrakte edilme yüzdesi en düşük olan bitkiler ise biberiye $(\% 0,39)$ ve kekik $(\% 0,59)$ 'tir $(p<0,05)$. Bitkilerde Fe mineralinin bulunma miktarı yüksek olsa da, bitki çayına geçme oranının oldukça düşük olduğu dikkati çekmektedir. Bu çalışmada bitki ve bitki çaylarının belirlenen Fe içerikleri, Pytlakowska ve ark (2012) [15]'nın çalışmasındaki sonuçlardan daha yüksektir. Adaçayı hariç diğer bitkilerden Fe mineralinin infüzyon tekniği ile ekstrakte edilme oranı, Başgel ve Erdemoğlu (2006) [11] tarafindan tespit edilen değerlerden daha yüksektir.

$\mathrm{Mg}$, bazı enzimlerin aktivasyonu için gerekli olan bir mineraldir. Fosfat gruplarının transferi ve hidrolizi, yağ, protein, nükleik asit sentezleri ve kasların kasılmasında önemli role sahiptir [20]. En yüksek Mg miktarı 1sırgan 
otunda, en düşük Mg miktarı da yeşilçayda olmak üzere bitkilerin Mg içerikleri 0,17 - 0,31 mg/g aralığındadır. Bir su bardağı $(200 \mathrm{~mL}$ ) bitki çayında belirlenen $\mathrm{Mg}$ miktarı ise $0,05 \mathrm{mg}$ (biberiye çayı) ile 0,36 mg (nane çayı) aralığında değişiklik göstermiştir. İnfüzyon işlemi sonucunda $\mathrm{Mg}$ minerali en düşük oranda biberiyeden (\% $10,48)$ ekstrakte edilebilirken, en yüksek oranda sinameki $(\% 60,48)$, nane $(\% 60,68)$ ve rezeneden $(\% 60,80)$ ekstrakte edilmiştir $(p<0,05)$. Sinameki, nane ve rezeneden $\mathrm{Mg}$ mineralinin ekstrakte edilme oranları arasında istatistiksel bir farklılık gözlenmemiştir $(p>0,05)$. Bitki ve bitki çaylarında belirlenen $\mathrm{Mg}$ miktarları, Başgel ve Erdemoğlu (2006) [11]'nun çalışmasında belirtilen değerlerden düşük, infüzyon yöntemiyle $\mathrm{Mg}$ mineralinin ekstrakte edilme yüzdesi yine aynı çalışmada ifade edilen değerlerden yüksektir.

$\mathrm{P}, \mathrm{Ca}$ ile birlikte kemik ve dişlerin oluşumunda rol almakta ve şeker fosfatları, nükleotidler, fosfoproteinler ve fosfolipitlerin yapısına katılarak vücut için önemli fonksiyonları yerine getirmektedir [22]. Bitkilerin $\mathrm{P}$ içeriklerinin birbirine benzer olduğu görülmüştür. Kekik, biberiye, papatya, adaçayı ve yeşilçayın P içeriği istatistiksel açıdan birbiriyle aynıdır ve $1,58-1,70 \mathrm{mg} / \mathrm{g}$ aralığında değişiklik göstermiştir ( $p>0,05)$. Adaçayı ve diğer bitkilerin P miktarları arasında da önemli bir farklılık bulgulanmamıştır ve P içerikleri 1,70 - 1,88 mg/g aralığındadır $(p>0,05)$. Yeşil çay $(1,96 \mathrm{mg} / 200 \mathrm{~mL})$, biberiye çayı $(1,97 \mathrm{mg} / 200 \mathrm{~mL})$, nane çayı $(1,97 \mathrm{mg} / 200$ $\mathrm{mL})$ ve sinameki çayının $(2,05 \mathrm{mg} / 200 \mathrm{~mL}) \mathrm{P}$ içerikleri istatistiksel açıdan birbirinden farksız $(p>0,05)$ ve diğer bitki çaylarına kıyasla en yüksektir $(p<0,05)$. Kekik çayı ise bir su bardağında $(200 \mathrm{~mL}) 1,59 \mathrm{mg}$ içermesiyle, $\mathrm{P}$ içeriği en düşük olan bitki çayı olarak tespit edilmiştir $(p<0,05)$. Bitkilerden infüzyon yöntemi ile $\mathrm{P}$ mineralinin ekstrakte edilebilirliği ise \% 48,55 (ıhlamur) ile \% 61,89 (yeşilçay) arasında değişiklik göstermiştir. Adaçayı dışında analizlenen bitkilerin P içerikleri, Pytlakowska ve ark (2012) [15]'nın bulgularından daha düşüktür. Ayrıca ısırgan otu çayı ve ıhlamur çayı dışındaki bitki çaylarının P içerikleri de aynı çalışmaya kıyasla daha düşük olarak tespit edilmiştir. Bitki çaylarında P mineralinin ekstrakte edilme oranı ise Gallaher ve ark (2006) [12]'nın sonuçlarına kıyasla nanede düşük, yeşil çayda ise daha yüksek olarak belirlenmiştir.

$\mathrm{Bu}$ çalışmada elde edilen veriler literatürle benzerlik ya da farklılıklar içermektedir. Bitkilerin mineral içeriklerinde gözlemlenen farklılıkların sebebi, yapıda bulunan minerallerin cinsi ve miktarının bitkinin yetiştiği toprak yapısı, iklim, toprağın ve bitkinin besin biriktirme yeteneği ve çevre kirliliği ile yakından ilişkili olmasıdır [8]. Örneğin, bitkinin asidik toprakta yetişmesi, minerallerin çözünürlüğünde artışa ve dolayısıyla yapıda mineral birikiminin daha fazla olmasına yol açmaktadır [6]. Bu nedenle, toprağın fiziksel ve kimyasal özellikleri de dahil olmak üzere bitki büyüme ortamındaki mevsimsel değişimler sonucunda bitkilerin mineral içeriğinin çok çeşitli olması beklenilen bir durumdur.

Bitki çaylarının mineral madde seviyeleri ise bitki çayının kompozisyonu ve hazırlanma yöntemi (infüzyon, dekoksiyon ya da soğuk maserasyon), bitkinin mineral içeriği, mineraller ile fenolik bileşikler gibi diğer matriks bileşenlerinin çözünürlüğü ve çay hazırlamada kullanılan suyun pH'sı gibi bir dizi parametreden kuvvetli bir şekilde etkilenmektedir. Her ne kadar mineral maddeler yüksek oranda ekstrakte edilebilir (> \% 55, örneğin K), orta derecede ekstrakte edilebilir (\% 22 - 55, örneğin Mg, Na, P, Zn) ve zayıf ekstrakte edilebilir $(<\%$ 20, örneğin $\mathrm{Ca}, \mathrm{Fe}, \mathrm{Mn}$ ) mineraller olmak üzere üç gruba ayrılsa da, çay hazırlama tekniğine bağlı olarak ekstrakte edilebilirlik oranı oldukça değişim göstermektedir. Bunun başlıca nedeni, bitki materyalinden infüzyon ya da dekoksiyon ortamına mineral maddenin salınım oranının bitkilerin fizyolojik özelliklerine, yapıdaki fenolik maddelerin ve diğer şelatlayıcı ve/veya bağlayıcı bileşenlerin seviyelerine, çaydaki mineral maddelerin konsantrasyonlarına, kullanılan suyun $\mathrm{pH}$ 'sına, infüzyon ortamının $\mathrm{pH}$ 'sına ve son olarak da uygulanan ekstraksiyon/hazırlama prosedürüne bağlı olarak değişimidir [8].

En yüksek ekstrakte edilebilirlik değerlerine $\mathrm{K}$, en düşük değerlere ise Fe mineralinin sahip olduğunun gözlendiği bu çalışmada, çay hazırlamada tridestile su kullanımının da mineral madde ekstrakte edilebilirliğini etkilediği düşünülmektedir. Bitki çayları, doğal kaynak suyu ya da içilebilir çeşme suyuyla hazırlansaydı, muhtemelen çayların mineral madde içerikleri daha yüksek tespit edilecekti. Analiz edilen bitki örneklerinin infüzyon yöntemi ile çay hazırlamaya uygun olmaları sebebiyle, çalışmada infüzyon tekniği tercih edilmiştir. Fakat unutulmamalıdır ki, infüzyon tekniği de dekoksiyon yöntemine göre mineral maddeleri daha az ekstrakte edebilen bir yöntemdir [8]. K mineralinin ekstrakte edilebilirliğinin yüksek olması, bitkilerde K'un inorganik türlerinin bulunduğunun ve Fe mineralinin ekstrakte edilebilirliğinin düşük olması ise Fe'in bitkilerin organik matrikslerine bağlı ya da immobilize halde olduğunun kanıtıdır. 


\section{E. NAKİLCIOĞLU-TAS}

Tablo 4. Bazı bitkilerin mineral madde içerikleri

\begin{tabular}{|c|c|c|c|c|c|c|c|c|c|c|}
\hline Bitkiler & $\mathrm{Zn}(\mu \mathrm{g} / \mathrm{g})$ & $\operatorname{Mn}(\mu \mathrm{g} / \mathrm{g})$ & $\mathrm{Na}(\mathrm{mg} / \mathrm{g})$ & K $(\mathrm{mg} / \mathrm{g})$ & $\mathrm{Cu}(\mu \mathrm{g} / \mathrm{g})$ & $\mathrm{Ca}(\mathrm{mg} / \mathrm{g})$ & $\mathrm{Fe}(\mu \mathrm{g} / \mathrm{g})$ & $\mathrm{Mg}(\mathrm{mg} / \mathrm{g})$ & $P(\mathrm{mg} / \mathrm{g})$ & $\begin{array}{c}\sum \text { Mineral } \\
\text { madde (mg/g) }\end{array}$ \\
\hline Kekik & $71,74 \pm 1,10^{\mathrm{f}}$ & $16,48 \pm 0,28^{\mathrm{f}}$ & $0,13 \pm 0,003^{\mathrm{g}}$ & $1,12 \pm 0,001^{\mathrm{a}}$ & $6,04 \pm 0,05^{\mathrm{b}}$ & $0,23 \pm 0,006^{\mathrm{d}, \mathrm{e}}$ & $249,24 \pm 0,32^{\mathrm{f}}$ & $0,23 \pm 0,001^{\mathrm{f}}$ & $1,52 \pm 0,10^{\mathrm{d}}$ & $3,57 \pm 0,06^{c}$ \\
\hline Nane & $88,95 \pm 0,29^{\mathrm{b}, \mathrm{c}}$ & $35,74 \pm 0,57^{\mathrm{b}}$ & $0,40 \pm 0,005^{\mathrm{b}}$ & $0,55 \pm 0,002^{\mathrm{c}}$ & $, 44 \pm 0,02^{\mathrm{a}}$ & $20 \pm 0,011^{\mathrm{e}}$ & $619,44 \pm 7,54^{\mathrm{a}}$ & $0,30 \pm 0,001^{\mathrm{b}}$ & $1,88 \pm 0,33^{\mathrm{a}}$ & $4,08 \pm 0,42^{\mathrm{b}}$ \\
\hline eki & $24^{\mathrm{e}}$ & $01 \pm 0,01^{\mathrm{g}}$ & $0,23 \pm 0,000^{\mathrm{d}}$ & $13 \pm 0,028^{\mathrm{a}}$ & 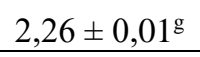 & $0,89 \pm 0,018^{\mathrm{b}}$ & $155,09 \pm 0,91^{\mathrm{g}}$ & $0,27 \pm 0,001^{\mathrm{d}}$ & $1,75 \pm 0,01^{\mathrm{a}, \mathrm{b}, \mathrm{c}}$ & 4,52 \\
\hline Bibe & $91,07 \pm 0,04^{\mathrm{a}, \mathrm{b}}$ & $25,72 \pm 0,13^{\mathrm{d}}$ & $0,16 \pm 0,004^{\mathrm{f}}$ & $1,12 \pm 0,000^{\mathrm{a}}$ & $2,35 \pm 0,04^{\mathrm{g}}$ & $0,24 \pm 0,004^{\mathrm{d}}$ & $287,85 \pm 0,11^{\mathrm{e}}$ & $0,22 \pm 0,001^{\mathrm{g}}$ & $1,59 \pm 0,11^{\mathrm{b}, \mathrm{c}, \mathrm{d}}$ & $3,74 \pm 0,01^{\mathrm{b}, \mathrm{c}}$ \\
\hline $\mathbf{R e}$ & $71,43 \pm 1,08^{f}$ & $3,99 \pm 0,08^{\mathrm{h}}$ & $0,32 \pm 0,001^{\mathrm{c}}$ & $14 \pm 0,003^{\mathrm{a}}$ & $5,14 \pm 0,12^{\mathrm{c}}$ & $, 06 \pm 0,002^{\mathrm{g}}$ & $68,34 \pm 0,70^{\mathrm{i}}$ & $0,23 \pm 0,000^{\mathrm{f}}$ & $1,83 \pm 0,10^{\mathrm{a}}$ & $3,74 \pm 0,12^{\mathrm{b}, \mathrm{c}}$ \\
\hline Pap: & $64,69 \pm 0,12^{\mathrm{g}}$ & $28,62 \pm 0,17^{\mathrm{c}}$ & $0,44 \pm 0,002^{\mathrm{a}}$ & $1,14 \pm 0,003^{\mathrm{a}}$ & $3,77 \pm 0,06^{\mathrm{e}}$ & $10 \pm 0,001^{\mathrm{f}}$ & $451,49 \pm 1,38^{c}$ & $0,21 \pm 0,003^{\mathrm{h}}$ & $1,56 \pm 0,08^{\mathrm{c}, \mathrm{d}}$ & $4,00 \pm 0,03^{\mathrm{b}}$ \\
\hline & $88,15 \pm 0,73^{\mathrm{c}}$ & $37,65 \pm 2,02^{\mathrm{b}}$ & $0,33 \pm 0,000^{\mathrm{c}}$ & $1,12 \pm 0,001^{\mathrm{a}}$ & $4,90 \pm 0,04^{\mathrm{d}}$ & & $508,64 \pm 6,05^{\mathrm{b}}$ & $0,26 \pm 0,002^{\mathrm{e}}$ & & $4,55 \pm 0,01^{\mathrm{a}}$ \\
\hline & $91,28 \pm 0,40^{\mathrm{a}, \mathrm{b}}$ & $19,38 \pm 0,09^{\mathrm{e}}$ & $0,15 \pm 0,001^{\mathrm{f}}$ & $1,13 \pm 0,002^{\mathrm{a}}$ & $2,94 \pm 0,01^{\mathrm{f}}$ & $0,25 \pm 0,004^{\mathrm{d}}$ & $415,29 \pm 1,72^{\mathrm{d}}$ & $0,28 \pm 0,000^{c}$ & $1,70 \pm 0,07^{\mathrm{a}, \mathrm{b}, \mathrm{c}, \mathrm{d}}$ & $4,04 \pm 0,08^{b}$ \\
\hline & $81,47 \pm 1,32^{\mathrm{d}}$ & $249,32 \pm 1,62^{\mathrm{a}}$ & $0,11 \pm 0,001^{\mathrm{h}}$ & $1,12 \pm 0,006^{\mathrm{a}}$ & $5,15 \pm 0,12^{\mathrm{c}}$ & $0,05 \pm 0,002^{\mathrm{g}}$ & $137,94 \pm 0,13^{\mathrm{h}}$ & $0,17 \pm 0,003^{\mathrm{i}}$ & $1,58 \pm 0,13^{\mathrm{b}, \mathrm{c}, \mathrm{d}}$ & $3,51 \pm 0,15^{\mathrm{c}}$ \\
\hline IsIrgan otu & $93,69 \pm 1,29^{a}$ & $18,01 \pm 0,20^{\mathrm{e}, \mathrm{f}}$ & $0,19 \pm 0,001^{\mathrm{e}}$ & $0,61 \pm 0,009^{b}$ & $5,15 \pm 0,01^{\mathrm{c}}$ & $1,18 \pm 0,006^{\mathrm{a}}$ & $446,73 \pm 2,50^{c}$ & $0,31 \pm 0,001^{\mathrm{a}}$ & $1,75 \pm 0,03^{\mathrm{a}, \mathrm{b}, \mathrm{c}}$ & $4,60 \pm 0,04^{\mathrm{a}}$ \\
\hline
\end{tabular}

Değerler, ortalama \pm standart sapma olarak ifade edilmiştir. Aynı sütundaki farklı harfler, $p<0,05$ 'te istatistiksel farklılıkları göstermektedir.

Tablo 5. İnfüzyon yöntemiyle hazırlanan bazı bitki çaylarının mineral madde içerikleri (200 mL bitki çayında bulunan mineral madde miktarı)

\begin{tabular}{|c|c|c|c|c|c|c|c|c|c|c|}
\hline Bitki çayları & $\mathrm{Zn}(\boldsymbol{\mu g})$ & Mn $(\mu \mathrm{g})$ & $\mathrm{Na}$ (mg) & K (mg) & $\mathrm{Cu}(\mu \mathrm{g})$ & $\mathrm{Ca}$ (mg) & $\mathrm{Fe}(\mu \mathrm{g})$ & Mg (mg) & $\mathbf{P}(\mathrm{mg})$ & $\begin{array}{c}\sum \text { Mineral } \\
\text { madde (mg) }\end{array}$ \\
\hline Kekik çayı & $45,93 \pm 5,36^{\mathrm{e}, \mathrm{f}}$ & $11,80 \pm 0,51^{\mathrm{c}, \mathrm{d}}$ & $0,10 \pm 0,002^{\mathrm{h}}$ & $1,57 \pm 0,001^{\mathrm{b}, \mathrm{c}}$ & $8,65 \pm 0,13^{\mathrm{a}}$ & $0,11 \pm 0,015^{\mathrm{d}}$ & $2,97 \pm 0,09^{\mathrm{g}}$ & $0,23 \pm 0,001^{\mathrm{g}}$ & $1,59 \pm 0,15^{\mathrm{c}}$ & $3,67 \pm 0,17^{\mathrm{e}}$ \\
\hline Nane çayı & $55,00 \pm 0,16^{\mathrm{c}, \mathrm{d}}$ & $23,45 \pm 0,00^{\mathrm{b}}$ & $0,43 \pm 0,002^{\mathrm{b}}$ & $0,72 \pm 0,023^{\mathrm{g}}$ & $3,58 \pm 0,03^{\mathrm{c}, \mathrm{d}}$ & $0,10 \pm 0,005^{\mathrm{d}, \mathrm{e}}$ & $13,65 \pm 0,10^{\mathrm{e}}$ & $0,36 \pm 0,001^{\mathrm{a}}$ & $1,97 \pm 0,08^{\mathrm{a}}$ & $3,68 \pm 0,03^{\mathrm{e}}$ \\
\hline i çayı & $43,12 \pm 0,08^{\mathrm{f}}$ & $10,10 \pm 0,02^{\mathrm{d}}$ & $0,23 \pm 0,003^{\mathrm{e}}$ & $1,56 \pm 0,011^{\mathrm{c}}$ & $2,28 \pm 0,06^{\mathrm{f}}$ & $0,95 \pm 0,036^{\mathrm{a}}$ & $19,15 \pm 0,68^{c}$ & $0,33 \pm 0,002^{\mathrm{c}}$ & $2,05 \pm 0,14^{\mathrm{a}}$ & $5,19 \pm 0,12^{\mathrm{a}}$ \\
\hline Biberi & $29,23 \pm 1,19^{\mathrm{g}}$ & t.e. ${ }^{\mathrm{e}}$ & $0,14 \pm 0,001^{\mathrm{g}}$ & $1,25 \pm 0,003^{\mathrm{d}}$ & $0,93 \pm 0,03^{\mathrm{h}}$ & $0,03 \pm 0,001^{\mathrm{f}}$ & $2,24 \pm 0,29^{\mathrm{g}}$ & $0,05 \pm 0,000^{\mathrm{i}}$ & $1,97 \pm 0,08^{\mathrm{a}}$ & $3,47 \pm 0,01^{\mathrm{f}}$ \\
\hline Rezen & $76,15 \pm 2,83^{\mathrm{a}}$ & t.e. e $^{\mathrm{s}}$ & $0,36 \pm 0,009^{c}$ & $0,80 \pm 0,001^{\mathrm{e}}$ & $5,06 \pm 0,07^{\mathrm{b}}$ & $0,04 \pm 0,001^{\mathrm{e}, \mathrm{f}}$ & $5,10 \pm 0,65^{\mathrm{f}}$ & $0,28 \pm 0,001^{\mathrm{e}}$ & $1,83 \pm 0,04^{b}$ & $3,40 \pm 0,06^{\mathrm{f}}$ \\
\hline Papatya çayı & $52,54 \pm 0,51^{\mathrm{c}, \mathrm{d}, \mathrm{e}}$ & $14,00 \pm 0,52^{\mathrm{c}}$ & $0,46 \pm 0,003^{\mathrm{a}}$ & $0,75 \pm 0,009^{\mathrm{f}}$ & $3,11 \pm 0,13^{\mathrm{e}}$ & $0,04 \pm 0,002^{e, f}$ & $28,62 \pm 0,46^{\mathrm{b}}$ & $0,25 \pm 0,001^{\mathrm{f}}$ & $1,72 \pm 0,01^{\mathrm{b}}$ & $3,32 \pm 0,00^{\mathrm{f}}$ \\
\hline çayı & $59,12 \pm 3,23^{\mathrm{c}}$ & $13,53 \pm 0,58^{\mathrm{c}, \mathrm{d}}$ & $0,25 \pm 0,002^{\mathrm{d}}$ & $1,59 \pm 0,014^{\mathrm{a}, \mathrm{b}}$ & $3,45 \pm 0,03^{\mathrm{d}}$ & $0,65 \pm 0,009^{\mathrm{c}}$ & $13,14 \pm 0,53^{\mathrm{e}}$ & $0,24 \pm 0,003^{\mathrm{g}}$ & $1,74 \pm 0,03^{b}$ & $4,56 \pm 0,07^{b}$ \\
\hline Adaçayı & $48,24 \pm 1,72^{\mathrm{d}, \mathrm{e}, \mathrm{f}}$ & $10,52 \pm 0,08^{\mathrm{c}, \mathrm{d}}$ & $0,09 \pm 0,001^{\mathrm{i}}$ & $1,61 \pm 0,002^{\mathrm{a}}$ & $1,78 \pm 0,02^{\mathrm{g}}$ & $0,11 \pm 0,003^{\mathrm{d}}$ & $20,13 \pm 1,63^{c}$ & $0,30 \pm 0,004^{\mathrm{d}}$ & $1,83 \pm 0,05^{\mathrm{b}}$ & $4,02 \pm 0,05^{\mathrm{d}}$ \\
\hline eşilçay & $58,67 \pm 0,01^{\mathrm{c}}$ & $292,72 \pm 3,40^{\mathrm{a}}$ & $0,08 \pm 0,001^{\mathrm{i}}$ & $1,59 \pm 0,000^{\mathrm{a}}$ & $3,36 \pm 0,01^{\mathrm{d}}$ & $0,03 \pm 0,001^{\mathrm{f}}$ & $33,37 \pm 0,32^{\mathrm{a}}$ & $0,19 \pm 0,003^{\mathrm{h}}$ & $1,96 \pm 0,04^{\mathrm{a}}$ & $4,23 \pm 0,03^{c}$ \\
\hline Isırgan otu çayı & $67,85 \pm 3,02^{b}$ & t.e. ${ }^{\mathrm{e}}$ & $0,20 \pm 0,007^{\mathrm{f}}$ & $0,56 \pm 0,004^{\mathrm{h}}$ & $3,77 \pm 0,07^{\mathrm{c}}$ & $0,84 \pm 0,046^{\mathrm{b}}$ & $16,60 \pm 0,13^{d}$ & $0,35 \pm 0,003^{b}$ & $1,82 \pm 0,06^{\mathrm{b}}$ & $3,86 \pm 0,15^{\mathrm{d}, \mathrm{e}}$ \\
\hline
\end{tabular}

Değerler, ortalama \pm standart sapma olarak ifade edilmiştir. Aynı sütundaki farklı harfler, $p<0,05$ 'te istatistiksel farklılıkları göstermektedir. 

MINERAL MADDE KAYNA ĞI OLARAK BAZI BITKİ VE BITKİ ÇAYLARININ ARAŞTIRMASI

Tablo 6. Bazı bitkilerden infüzyon işlemiyle mineral maddelerin ekstrakte edilme yüzdeleri (\%)

\begin{tabular}{|c|c|c|c|c|c|c|c|c|c|c|}
\hline Bitkiler & Zn & Mn & $\mathbf{N a}$ & $\mathbf{K}$ & $\mathbf{C u}$ & $\mathbf{C a}$ & $\mathbf{F e}$ & Mg & $\mathbf{P}$ & $\begin{array}{c}\sum \text { Mineral } \\
\text { madde } \\
\text { ekstrakte } \\
\text { edilebilirliği }\end{array}$ \\
\hline Kekik & $31,85 \pm 4,20^{\mathrm{c}, \mathrm{d}, \mathrm{e}}$ & $35,58 \pm 2,13^{\mathrm{c}}$ & $39,82 \pm 0,02^{\mathrm{e}}$ & $69,39 \pm 0,05^{\mathrm{a}}$ & $71,13 \pm 1,61^{\mathrm{a}}$ & $23,40 \pm 3,89^{\mathrm{d}, \mathrm{e}}$ & $0,59 \pm 0,02^{\mathrm{h}, \mathrm{i}}$ & $49,58 \pm 0,06^{\mathrm{e}}$ & $52,18 \pm 6,69^{\mathrm{c}, \mathrm{d}}$ & $51,33 \pm 3,26^{\mathrm{b}}$ \\
\hline Nane & $30,79 \pm 0,19^{\mathrm{c}, \mathrm{d}, \mathrm{e}}$ & $32,69 \pm 0,52^{\mathrm{d}}$ & $53,52 \pm 0,85^{\mathrm{a}, \mathrm{b}}$ & $65,42 \pm 1,28^{\mathrm{b}}$ & $27,65 \pm 0,19^{\mathrm{g}}$ & $24,73 \pm 0,15^{\mathrm{d}, \mathrm{e}}$ & $1,10 \pm 0,01^{\mathrm{g}, \mathrm{h}}$ & $60,68 \pm 0,14^{\mathrm{a}}$ & $53,64 \pm 9,61^{\mathrm{a}, \mathrm{b}, \mathrm{c}, \mathrm{d}}$ & $45,36 \pm 5,03^{\mathrm{c,d}}$ \\
\hline Sinameki & $28,74 \pm 0,04^{\mathrm{d}, \mathrm{e}}$ & $62,64 \pm 0,06^{\mathrm{a}}$ & $48,82 \pm 0,50^{\mathrm{c}}$ & $68,55 \pm 1,54^{\mathrm{a}}$ & $50,24 \pm 1,46^{\mathrm{b}}$ & $52,70 \pm 3,06^{\mathrm{b}}$ & $6,14 \pm 0,25^{\mathrm{b}}$ & $60,48 \pm 0,25^{\mathrm{a}, \mathrm{b}}$ & $58,08 \pm 3,34^{\mathrm{a}, \mathrm{b}, \mathrm{c}}$ & $57,37 \pm 0,51^{\mathrm{a}}$ \\
\hline Biberiye & $15,91 \pm 0,64^{\mathrm{f}}$ & - & $43,58 \pm 0,79^{\mathrm{d}}$ & $55,33 \pm 0,10^{\mathrm{c}}$ & $19,62 \pm 0,40^{\mathrm{h}}$ & $5,76 \pm 0,16^{\mathrm{f}}$ & $0,39 \pm 0,05^{\mathrm{i}}$ & $10,48 \pm 0,05^{\mathrm{g}}$ & $61,86 \pm 4,76^{\mathrm{a}}$ & $46,36 \pm 0,25^{\mathrm{b}, \mathrm{c}, \mathrm{d}}$ \\
\hline Rezene & $53,13 \pm 2,78^{a}$ & - & $55,40 \pm 1,56^{\mathrm{a}}$ & $35,06 \pm 0,05^{\mathrm{e}}$ & $49,05 \pm 1,90^{\mathrm{b}}$ & $32,26 \pm 0,05^{\mathrm{c}}$ & $3,71 \pm 0,43^{\mathrm{c}}$ & $60,80 \pm 0,24^{\mathrm{a}}$ & $49,85 \pm 3,37^{\mathrm{c}, \mathrm{d}}$ & $45,49 \pm 2,26^{\mathrm{c}, \mathrm{d}}$ \\
\hline Papatya & $40,33 \pm 0,47^{\mathrm{b}}$ & $24,29 \pm 0,76^{\mathrm{f}}$ & $51,68 \pm 0,14^{\mathrm{b}}$ & $32,73 \pm 0,34^{\mathrm{f}}$ & $40,94 \pm 1,06^{\mathrm{c}}$ & $21,00 \pm 0,88^{\mathrm{e}}$ & $3,15 \pm 0,06^{\mathrm{d}}$ & $59,11 \pm 0,72^{\mathrm{b}}$ & $55,03 \pm 2,25^{\mathrm{a}, \mathrm{b}, \mathrm{c}, \mathrm{d}}$ & $41,57 \pm 0,23^{\mathrm{d}}$ \\
\hline Ihlamur & $33,51 \pm 1,56^{\mathrm{c}, \mathrm{d}}$ & $17,98 \pm 0,19^{\mathrm{g}}$ & $37,97 \pm 0,32^{\mathrm{e}}$ & $70,49 \pm 0,47^{\mathrm{a}}$ & $35,24 \pm 0,57^{\mathrm{d}, \mathrm{e}}$ & $77,90 \pm 3,38^{\mathrm{a}}$ & $1,29 \pm 0,04^{\mathrm{f}, \mathrm{g}}$ & $45,61 \pm 0,83^{\mathrm{f}}$ & $48,55 \pm 0,22^{\mathrm{d}}$ & $50,08 \pm 0,68^{\mathrm{b}, \mathrm{c}}$ \\
\hline Adaçayı & $26,22 \pm 1,05^{\mathrm{e}}$ & $26,91 \pm 0,34^{\mathrm{e}}$ & $27,99 \pm 0,27^{\mathrm{g}}$ & $70,65 \pm 0,15^{\mathrm{a}}$ & $30,00 \pm 0,24^{\mathrm{f}, \mathrm{g}}$ & $22,05 \pm 1,03^{\mathrm{e}}$ & $2,41 \pm 0,21^{\mathrm{e}}$ & $53,87 \pm 0,81^{\mathrm{d}}$ & $53,14 \pm 1,34^{\mathrm{b}, \mathrm{c}, \mathrm{d}}$ & $49,70 \pm 0,43^{\mathrm{b}, \mathrm{c}}$ \\
\hline Yeşilçay & $35,88 \pm 0,59^{b, c}$ & $58,47 \pm 0,30^{\mathrm{b}}$ & $33,47 \pm 0,46^{\mathrm{f}}$ & $70,69 \pm 0,28^{\mathrm{a}}$ & $32,51 \pm 0,90^{\mathrm{e}, \mathrm{f}}$ & $29,97 \pm 0,36^{\mathrm{c}, \mathrm{d}}$ & $12,05 \pm 0,11^{\mathrm{a}}$ & $54,27 \pm 0,26^{\mathrm{d}}$ & $61,89 \pm 3,51^{\mathrm{a}, \mathrm{b}}$ & $60,37 \pm 2,13^{\mathrm{a}}$ \\
\hline Isırgan otu & $35,94 \pm 2,09^{\mathrm{b}, \mathrm{c}}$ & - & $53,36 \pm 1,60^{\mathrm{a}, \mathrm{b}}$ & $45,69 \pm 0,71^{\mathrm{d}}$ & $36,32 \pm 0,57^{\mathrm{d}}$ & $35,22 \pm 2,10^{\mathrm{c}}$ & $1,84 \pm 0,03^{\mathrm{f}}$ & $56,16 \pm 0,41^{\mathrm{c}}$ & $51,13 \pm 1,66^{\mathrm{c}, \mathrm{d}}$ & $41,96 \pm 2,01^{\mathrm{d}}$ \\
\hline
\end{tabular}

Değerler, ortalama \pm standart sapma olarak ifade edilmiştir. Aynı sütundaki farklı harfler, $p<0,05$ 'te istatistiksel farklılıkları göstermektedir. 


\section{E. NAKILCIOĞLU-TAŞ}

Tablo 7'de 19-50 yaş arası yetişkin kadın ve erkekler için günlük önerilen mineral alım miktarları verilmektedir. Bu çalışmanın sonucunda görülmektedir ki, kadınlar günde 10 bardak, erkekler ise 13 bardak rezene çayı tüketmeleri durumunda günlük almaları önerilen $\mathrm{Zn}$ miktarının \% 10'unu rezene çayından karşıllayabilirler.

Tablo 7. Türkiye'ye Özgü Beslenme Rehberine göre yetişkinler (19-50 yaş) için önerilen minerallerin günlük yeterli alım miktarları [23]

\begin{tabular}{|c|c|c|}
\hline \multirow{2}{*}{ Mineral madde } & \multicolumn{2}{|c|}{ Cinsiyet } \\
\cline { 2 - 3 } & Kadı & Erkek \\
\hline $\mathbf{Z n}$ & $7,5-12,6 \mathrm{mg}$ & $3,4-16,3 \mathrm{mg}$ \\
\hline $\mathbf{M n}$ & $3 \mathrm{mg}$ & $1,5 \mathrm{~g}$ \\
\hline $\mathbf{N a}$ & $1,5 \mathrm{~g}$ & $4,7 \mathrm{~g}$ \\
\hline $\mathbf{K}$ & $4,7 \mathrm{~g}$ & $1,6 \mathrm{mg}$ \\
\hline $\mathbf{C u}$ & $1,3 \mathrm{mg}$ & $950-1000 \mathrm{mg}$ \\
\hline $\mathbf{C a}$ & $950-1000 \mathrm{mg}$ & $11 \mathrm{mg}$ \\
\hline $\mathbf{F e}$ & $11-16 \mathrm{mg}$ & $350 \mathrm{mg}$ \\
\hline $\mathbf{M g}$ & $300 \mathrm{mg}$ & $550 \mathrm{mg}$ \\
\hline $\mathbf{P}$ & $550 \mathrm{mg}$ & \\
\hline
\end{tabular}

Günde 1 bardak yeşilçay tüketimi, günlük alınması gereken Mn miktarının \% 97,57'sini karşılamaktadır. Adaçayı ve yeşilçay tüketimi, düşük Na içeriği sebebiyle, özellikle tansiyon hastaları tarafından tercih edilebilir. Günlük $\mathrm{Cu}$ ihtiyacının \% 10'unu karşılamak için kadınların yaklaşık 15, erkeklerin ise 18 bardak kekik çayı tüketmeleri gerekmektedir. Çalışılan bitki çaylarının düşük $\mathrm{Mg}, \mathrm{Fe}, \mathrm{P}, \mathrm{Ca}$ ve $\mathrm{K}$ kaynakları oldukları görülmektedir.

\section{SONUÇLAR}

Türkiye'de bitki çayı tüketimi oldukça popülerdir. Günlük diyette sıklıkla yer alan bitki çaylarının mineral madde içerikleri, farklı bitki çeşitleri ve bitki çayı hazırlama yöntemleri gibi pek çok etmenin sonucunda geniş bir aralıkta değişim göstermektedir. Genel olarak, bu içecekler yadsınmayacak derecede mineral kaynağıdırlar. Vücudun biyolojik fonksiyonlarını sorunsuz bir biçimde sürdürebilmesi için günlük alınması gereken $\mathrm{Zn}, \mathrm{Mn}$, $\mathrm{Na}, \mathrm{K}, \mathrm{Cu}, \mathrm{Ca}, \mathrm{Fe}, \mathrm{Mg}$ ve $\mathrm{P}$ miktarını karşılamaya destek olmaktadırlar. Bitki çayı tüketimi ile mineral maddelerin yanı sıra, bitkilerin yapılarında bulunan ve infüzyon yöntemiyle çay fazına geçebilen fenolik bileşikler gibi antioksidan özellikli maddeler de vücuda alınmaktadır. Bu durum bitki çayı tüketiminin, sağlığın korunmasında çok yönlü etkisinin olduğunun bir göstergesidir.

\section{TEŞEKKÜR}

Nesli Geray ve Ümran Ezilmeztürk’e kişisel yardımlarından dolayı teşekkür ederim.

\section{KAYNAKLAR}

[1] JIN, L., LI, X.-B., TIAN, D.-Q., FANG, X.-P., YU, Y.-M. \& ZHU, H.-Q., “Antioxidant Properties and Color Parameters of Herbal Teas in China," Industrial Crops and Products, 87, 198-209, 2016.

[2] MAlONGANE, F., MCGAW, L. J., NYONI, H. \& MUDAU, F. N., "Metabolic Profiling of Four South African Herbal Teas Using High Resolution Liquid Chromatography-Mass Spectrometry and Nuclear Magnetic Resonance," Food Chemistry, 257, 90-100, 2018.

[3] ZHAO, J., DENG, J. W., CHEN, Y. W. \& LI, S. P., “Advanced Phytochemical Analysis of Herbal Tea in China," Journal of Chromatography A, 1313, 2-23, 2013.

[4] SCHUlZ, V., HÄNSEL, R. \& TYLER, V. E., Rational Phytotherapy: A Physicians' Guide to Herbal 
Medicine. Germany: Springer Berlin Heidelberg, 2001.

[5] CAPASSO, F., GAGINElla, T. S., GRANDOLINI, G. \& IZZO, A. A., Phytotherapy: A Quick Reference to Herbal Medicine. Germany: Springer Berlin Heidelberg, 2003.

[6] POHL, P., DZIMITROWICZ, A., JEDRYCZKO, D., SZYMCZYCHA-MADEJA, A., WELNA, M. \& JAMROZ, P., "The Determination of Elements in Herbal Teas and Medicinal Plant Formulations and Their Tisanes," Journal of Pharmaceutical and Biomedical Analysis, 130, 326-335, 2016.

[7] MILANI, R. F., DE PAIVA, E. L., PERON, L. I., MORGANO, M. A. \& CADORE, S., “Arsenic Species in Herbal Tea Leaves and Infusions Determination by HPLC-ICP-MS," LWT - Food Science and Technology, 98, 606-612, 2018.

[8] MILANI, R. F., SILVESTRE, L. K., MORGANO, M. A. \& CADORE, S., "Investigation of Twelve Trace Elements in Herbal Tea Commercialized in Brazil," Journal of Trace Elements in Medicine and Biology, $52,111-117,2019$.

[9] MARTíN-DOMINGO, M. C., PLA, A. I., HERNÁNDEZ, A. F., OLMEDO, P., NAVAS-ACIEN, A., LOZANO-PANIAGUA, D., GIL, F., "Determination of Metalloid, Metallic and Mineral Elements in Herbal Teas. Risk Assessment for the Consumers," Journal of Food Composition and Analysis, 60, 81-89, 2017.

[10] KARA, D., "Evaluation of Trace Metal Concentrations in Some Herbs and Herbal Teas by Principal component Analysis," Food Chemistry, 114(1), 347-354, 2009.

[11] BAŞGEL, S. \& ERDEMOĞLU, S. B., "Determination of Mineral and Trace Elements in Some Medicinal Herbs and Their Infusions Consumed in Turkey," Science of the Total Environment, 359, 82-89, 2006.

[12] GALLAHER, R. N., GALLAHER, K., MARSHALl, A. J. \& MARSHALL A. C., "Mineral Analysis of Ten Types of Commercially Available Tea," Journal of Food Composition and Analysis, 19, S53-S57, 2006.

[13] NOOKABKAEW, S., RANGKADILOK, N. \& SATAYAVIVAD, J., "Determination of Trace Elements in Herbal Tea Products and Their Infusions Consumed in Thailand," Journal of Agricultural and Food Chemistry, 54, 6939-6944, 2006.

[14] ÖZCAN, M. M., ÜNVER, A., UÇAR, T. \& ARSLAN, D., "Mineral Content of Some Herbs and Herbal Teas by Infusion and Decoction," Food Chemistry, 106, 1120-1127, 2008.

[15] PYTLAKOWSKA, K., KITA, A., JANOSKA, P., POŁOWNIAK, M. \& KOZIK, V., "Multi-Element Analysis of Mineral and Trace Elements in Medicinal Herbs and Their Infusions," Food Chemistry, 135(2), 494-501, 2012.

[16] OLIVIER, J., SYMINGTON, E. A., JONKER, C. Z., RAMPEDI, I. T. \& VAN EEDEN, T. S., "Comparison of the Mineral Composition of Leaves and Infusions of Traditional and Herbal Teas," The South African Journal of Science, 108(1/2), 1-7, 2012.

[17] MALIK, J., FRANKOVA, A., DRABEK, O., SZAKOVA, J., ASH, C. \& KOKOSKA, L., "Aluminium and Other Elements in Selected Herbal Tea Plant Species and Their Infusions," Food Chemistry, 139, 728-734, 2013.

[18] SZYMCZYCHA-MADEJA, A., WELNA, M. \& POHL, P., "Simple and Fast Sample Preparation Procedure Prior to Multi-Element Analysis of Slim Teas by ICP OES," Food Analytical Methods, 7(10), 2051-2063, 2014.

[19] AOAC METHODS 965.17-1966 (Association of Official Analytical Chemist), Phosphorus in Animal Feed and Pet Food, Arlington, VA, 1996.

[20] ERDOĞAN, S., ERGÜN, Y., ERDOĞAN, Z. \& KONTAŞ, T., "Hatay Bölgesinde Merada Yetiştirilen Koyun ve Keçi Serumlarında Bazı Mineral Madde Düzeyleri," Turkish Journal of Veterinary and Animal Sciences, 26(1), 177-182, 2002.

[21] YERLIKAYA, H. \& TOKER, A., "Obezite ve Eser Elementler," Endokrinolojide Diyalog, 9(2), 64-70, 2012.

[22] ÖTLEŞ, S., ÖZDESTAN OCAK, Ö., NAKILCIOĞLU TAŞ, E., KARTAL, C. \& ÖZYURT, V. H., Gida Kimyası, 2. Baskı, İzmir: Ege Üniversitesi Basımevi, 2016.

[23] PEKCAN, G., ŞANLIER, N. \& BAŞ, M., Turkey Dietary Guidelines, Ankara: Ministry of Turkey Health Publication No:1046, 2016. 